University of Nebraska - Lincoln

DigitalCommons@University of Nebraska - Lincoln

2005

\title{
Indirect interaction between two native thistles mediated by an invasive exotic floral herbivore
}

\author{
F. Leland Russell \\ University of Nebraska - Lincoln, leland.russell@wichita.edu \\ Svata M. Louda \\ University of Nebraska - Lincoln, slouda1@unl.edu
}

Follow this and additional works at: https://digitalcommons.unl.edu/bioscifacpub

Part of the Life Sciences Commons

Russell, F. Leland and Louda, Svata M., "Indirect interaction between two native thistles mediated by an invasive exotic floral herbivore" (2005). Faculty Publications in the Biological Sciences. 58.

https://digitalcommons.unl.edu/bioscifacpub/58

This Article is brought to you for free and open access by the Papers in the Biological Sciences at DigitalCommons@University of Nebraska - Lincoln. It has been accepted for inclusion in Faculty Publications in the Biological Sciences by an authorized administrator of DigitalCommons@University of Nebraska - Lincoln. 


\title{
Indirect interaction between two native thistles mediated by an invasive exotic floral herbivore
}

\author{
F. Leland Russell and Svata M. Louda
}

School of Biological Sciences, University of Nebraska-Lincoln, Lincoln, NE 68588-0118, USA

Current address for F. L. Russell - Department of Biological Sciences, Wichita State University, Wichita, KS 67260, USA; email leland.russell@wichita.edu

\begin{abstract}
Spatial and temporal variation in insect floral herbivory is common and often important. Yet, the determinants of such variation remain incompletely understood. Using 12 years of flowering data and 4 years of biweekly insect counts, we evaluated four hypotheses to explain variation in damage by the Eurasian flower head weevil, Rhinocyllus conicus, to the native North American wavyleaf thistle, Cirsium undulatum. The four factors hypothesized to influence weevil impact were variations in climate, weevil abundance, phenological synchrony, and number of flower heads available, either on wavyleaf thistle or on the other co-occurring, acquired native host plant (Platte thistle, Cirsium canescens), or on both. Climate did not contribute significantly to an explanation of variation in $R$. conicus damage to wavyleaf thistle. However, climate did influence weevil synchrony with wavyleaf flower head initiation, and phenological synchrony was important in determin$\operatorname{ing} R$. conicus oviposition levels on wavyleaf thistle. The earlier $R$. conicus was active, the less it oviposited on wavyleaf thistle, even when weevils were abundant. Neither weevil abundance nor availability of wavyleaf flower heads predicted $R$. conicus egg load. Instead, the strongest predictor of $R$. conicus egg load on wavyleaf thistle was the availability of flower heads on Platte thistle, the more common, earlier flowering native thistle in the sand prairie. Egg load on wavyleaf thistle decreased as the number of Platte thistle flower heads at a site increased. Thus, wavyleaf thistle experienced associational defense in the presence of flowering by its now declining native congener, Platte thistle. These results demonstrate that prediction of damage to a native plant by an exotic insect may require knowledge of both likely phenological synchrony and total resource availability to the herbivore, including resources provided by other nontarget native species.
\end{abstract}

Keywords: associational defense, biocontrol, invasive species, insect herbivory, phenological synchrony

\section{Introduction}

A striking characteristic of insect herbivory in natural systems is its variability (Crawley 1983, 1992; Louda 1989; Leimu et al. 2002). Seed losses to insect floral feeders and predispersal seed predators can vary more than two- to sixfold among populations of a host species (Louda 1982a, 1983; Leimu et al. 2002). The causes of such variation among plant populations and years, however, are poorly understood for coevolved plant-insect interactions, and even less so for interactions involving invasive exotic insects. A better understanding of the mechanisms underlying variation in herbivory is critical to predicting the conditions under which herbivores, native or exotic, will affect either plant population densities (Louda 1982b, 1983; Louda and Potvin 1995; Kelly and Dyer 2002; Maron et al. 2002, Rose et al. 2005) or distributions (Louda 1982a, 1983; Louda et al. 1987; Smith 1987, Louda and Rodman 1996).

Climatic factors, such as temperature and precipitation, can affect both insect activity and plant performance (e.g., Rathcke and Lacey 1985; Tauber et al. 1986). For some floral herbivore-host plant interactions, effects of climate on insect herbivores or on their host plants are sufficiently direct and strong to determine the level of herbivore damage (Solbreck and Sillen-Tullberg 1986). However, in many instances climate effects on insect and plant popula- 
tions may be weak or may be sufficiently complex so that accurate prediction of damage may require knowledge of the population dynamics of herbivore and host plant, and possibly of alternate host species as well.

Three leading hypotheses that focus upon the direct interaction between herbivore and host plant to explain spatial and temporal variation in rates of floral herbivory/ pre-dispersal seed predation are the masting hypothesis (Janzen 1971, Koenig and Knops 2000), the phenological window hypothesis (Aizen and Patterson 1995), and the resource concentration hypothesis (Root 1972; Hamback and Beckerman 2003). The masting hypothesis suggests that variation in herbivore-caused seed loss occurs because large temporal variations in host plant flowering alter the ratio of floral/seed resources to herbivore numbers (Janzen 1971; Koenig and Knops 2000). The phenological window hypothesis suggests that variation in herbivorecaused seed loss is a response to variation in the degree of overlap in insect activity with floral/seed resources. The resource concentration hypothesis suggests that variation in herbivore-caused seed loss is a response to variation in resource availability (Root 1972; Hamback and Beckerman 2003). If such direct interactions primarily determine levels of insect damage, then properties of the herbivore and the host plant population should explain temporal and spatial variation in damage to that host plant.

However, theory suggests that indirect, herbivore-mediated interactions between plants may occur when they share a significant herbivore (Holt 1977). If the insect aggregates in resource-rich patches, then co-occurrence with an alternate host species may lead to an increase in damage, called "associational susceptibility" (Holt 1977). Alternately, if the insect has a preference for the alternative host, then co-occurrence with that species may lead to a decrease in damage, called "associational defense" (Tahvanainen and Root 1972). If indirect effects predominate, then damage to one host species can be predicted only with information about populations of other co-occurring, alternate host species. Holt and Hochberg (2001) extended this theory of indirect interaction effects, predicting that damage to newly adopted, native plant hosts by exotic insects introduced for weed biocontrol should be affected by the abundance of the targeted exotic weed. The possibility, however, that biocontrol insects may mediate novel indirect effects among adopted, native hosts has rarely been considered.

In this study we evaluated direct and indirect effects of both abiotic and biotic factors, previously hypothesized to predict variation in herbivore load, in the interaction and impact of the invasive flower head weevil, Rhinocyllus conicus Fröl., with the native wavyleaf thistle (Cirsium undulatum Spreng.) in sand prairie in the northern Great Plains. In these prairies, R. conicus oviposits not only on wavyleaf thistle, but it also has heavily impacted a second, native thistle, Platte thistle (C. canescens Nutt.) (Louda et al. 1997; Louda and Arnett 2000; Louda et al. 2003; Rose et al. 2005).
To examine the mechanisms that drive variation among sites and years in $R$. conicus damage to wavyleaf thistle, we systematically evaluated a series of hypotheses, each of which incorporated a greater degree of biological complexity than its predecessor. First, we examined the hypothesis that variation in key climate parameters will predict variation in $R$. conicus egg load on wavyleaf thistle. Second, we examined the ability of three direct biotic mechanisms to predict the R. conicus egg load. These were variations in $R$. conicus abundance, synchrony of $R$. conicus and wavyleaf thistle, and availability of wavyleaf flower head resources. Finally, we examined the degree to which indirect effects, specifically either total thistle flower head availability on both wavyleaf thistle and Platte thistles or Platte thistle flower head availability only, predicted $R$. conicus egg load on wavyleaf thistle. We found that the indirect effects were strongest; $R$. conicus egg load on wavyleaf thistle was inversely related to the availability of Platte thistle flower heads.

\section{Methods}

\section{Natural history and background}

The data were collected at six sites within two preserves owned by The Nature Conservancy in the $49,000 \mathrm{~km}^{2}$ Nebraska Sand Hills, the largest continental dune grassland in the western hemisphere (Bleed and Flowerday 1989). The two preserves were Arapaho Prairie Preserve in Arthur County, NE $\left(41^{\circ} 30^{\prime} \mathrm{N}, 101^{\circ} 52^{\prime} \mathrm{W}\right)$ in the southwest, and Niobrara Valley Preserve in Brown County, NE $\left(42^{\circ} 46^{\prime} \mathrm{N}, 100^{\circ} \mathrm{W}\right)$, in the north-central Sand Hills, $270 \mathrm{~km}$ from Arapaho.

Wavyleaf thistle (C. undulatum Spreng.), although widespread in the Great Plains, is relatively sparse in the Sand Hills (Great Plains Flora Association 1986). Its iterocarpic life history in this region contrasts with that of the predominant Sand Hills species, Platte thistle (C. canescens), which is monocarpic. Flower head development of wavyleaf thistle occurs from early June to mid-August, about three weeks after that of Platte thistle (Great Plains Flora Association 1986; Louda 1998).

The weevil $R$. conicus is a flower head feeding thistle specialist that was introduced into North America from Europe in 1968, and into eastern Nebraska 1969-1972, as a biological control agent for exotic Carduus spp. thistles, especially musk thistle, C. nutans L. (Zwölfer and Harris 1984; Gassmann and Louda 2001). The weevil oviposits on external bracts of developing flower heads, covering each egg with an obvious case of masticated plant tissue. Larvae burrow into the flower head, where they consume receptacle tissues, florets, ovules, and developing seeds. Development takes 53-76 days, allowing one generation per year (Zwölfer and Harris 1984). After 1993-1994, when R. conicus invaded our long-term Sand Hills study sites, its numbers increased significantly on 
both of the native thistles (Louda et al. 1997, 1998; Louda 1998, 2000). No exotic thistles occurred in our Sand Hills sites.

\section{Field data}

Sampling procedures for wavyleaf thistle paralleled those used previously in studies of Platte thistle (Louda 2000; Russell and Louda 2004; Rose et al. 2005). To quantify flowering and floral herbivory, we sampled adult plants at two sites at each preserve 1991-2001. In May at each site, we marked every wavyleaf rosette that was large enough to flower that occurred along a walked transect until a sample of thistles was designated. The number of plants sampled per site varied with availability $(N=5-12$ per site per year, mean $=7)$. At Niobrara, the same sites were used in all years (Inner Salzman, Outer Salzman). At Arapaho, sites differed among years but always included two of four (Gate, Shed, Midwest, West Foothills).

Sampled plants were measured at four stages of development: (1) early (late May), when wavyleaf plants were initiating flower buds and $R$. conicus adults were active; (2) midseason (late June), when wavyleaf plants had initiated most of their flower heads and $R$. conicus was finishing oviposition; (3) late season (late July) when wavyleaf thistle flowering was almost complete and no adult $R$. conicus remained; and (4) end of season (late August) when the last wavyleaf flower heads had matured seed. These measurements are sufficient to derive the shape of the plant flowering phenology distribution and to quantify R. conicus oviposition levels (Louda 1998, 2000; Rose et al. 2005). On each date, we recorded diameter and developmental stage of all of the flower heads on each marked plant. The stages were small bud, large bud, partial flower, full flower, maturing seed, and dispersed (as in Lamp and McCarty 1981; Bevill et al. 1999). We identified and counted all insects present. In 1996, in addition to noting presence, we began counting the number of $R$. conicus egg cases per head. Counts of flower heads and weevil egg loads on Platte thistle at these sites, used to quantify total resources and compare egg loads, are from a parallel study of Platte thistle (Russell and Louda 2004). We also intensively sampled insects on the marked thistles (1997-2000), to better quantify the abundance and phenology of $R$. conicus adults, by counting weevils twice weekly (mean $=4$ days; range 3-5 days, depending on weather) May through July.

Daily climate data (1989-2001) came from the Nebraska automated data network stations at Arapaho Prairie and at the town of Ainsworth, $20 \mathrm{~km}$ southeast of the Niobrara Valley Preserve (available through the High Plains Climate Center, University of NebraskaLincoln). The climate variables, suggested as important for insect or plant dynamics and evaluated in this study, were three measures of temperature variation [total growing degree-days (GDD) above $4.4^{\circ} \mathrm{C}\left(40^{\circ} \mathrm{F}\right)$ by season, days in spring to last hard freeze $\left(<-3.9^{\circ} \mathrm{C}\right)$, and days to last freeze $\left(0^{\circ} \mathrm{C}\right)$ from 1 January]; and, two measures of environmental moisture [mean daily precipitation, relative humidity by season]. We defined seasons as winter = January-March; spring = April-June; summer $=$ July-September; and autumn = October-December. Climate variables were standardized for each preserve by subtracting the mean and dividing by the standard deviation.

\section{Statistical analyses}

\section{Patterns of variation}

Weevil abundance and egg loads - To determine whether adult weevil abundance varied among preserves and years, we used a $2 \times 4$ contingency table analysis. To evaluate the relationship between weevil abundance and phenology, we used a Pearson product-moment correlation. To estimate relative abundance of $R$. conicus adults at each preserve in each year (1997-2000), we used the cumulative number of $R$. conicus adults observed at the 4-day intervals. This measure may involve some redundancy, but it should be comparable among preserves and years. To compare counts across years, we standardized adult weevil counts to number per ten plants. We used KruskalWallis tests to compare mean number of $R$. conicus egg cases per flower head per wavyleaf thistle plant among years (1996-2001) at each preserve. We used a Wilcoxon ranked sum test to compare weevil egg load on wavyleaf thistle among preserves.

Flower head availability - We used two-way ANOVA on log-transformed counts to determine whether the total number of C. undulatum flower heads in late July differed significantly between preserves and years (19912001). Contrasts were used to detect differences between preserves in each year, using the conservative Bonferroni correction to adjust significant thresholds for multiple comparisons. Since our focus was on population interactions, the total number of flower heads observed was standardized to ten plants per preserve. This estimate incorporates variation in individual plant size. Also, it provides a reasonable index of preserve-specific flower head availability since it reflects the relationship observed between size, flowering effort, and plant density in demography plots at each preserve (S. M. Louda and K. H. Keeler, unpublished data).

Phenology and synchrony - To quantify phenologies, we calculated the proportion of the cumulative number of weevils, and the cumulative number of flower heads initiated per plant, that occurred in late May, the usual peak in R. conicus numbers (Russell and Louda 2004). Proportions were arcsine-transformed before analysis. To estimate the degree of phenological synchrony of $R$. conicus with wavyleaf thistle flowering, we defined a 
measure of population synchrony as the difference between the proportion of total weevils and the proportion of total C. undulatum heads observed in late May. We refer to this difference as the "degree $R$. conicus preceded C. undulatum." This measure was positive when $R$. conicus was earlier than wavyleaf thistle, and negative when wavyleaf thistle was earlier. Larger absolute values for this measure indicate greater asynchrony of weevil and thistle populations than smaller absolute values. Since the date of sampling in May varied between years (Niobrara: 21-31 May; Arapaho: 24-31 May), we asked if date affected our estimate of the proportions observed in May. For wavyleaf flower heads, it did (linear regression: $P<0.001$, both preserves); so, for the analysis of wavyleaf thistle phenology, we analyzed the residuals from the regression of transformed proportions of flower heads on sampling date. Date of sampling did not affect either the proportion of $R$. conicus adults observed or the degree $R$. conicus preceded wavyleaf thistle. To test for variation in wavyleaf phenology among preserves and years (1991-2001), we used two-way ANOVA and Fischer's LSD to evaluate differences. We used a $2 \times 4$ $\times 2$ contingency table analysis to determine whether the number of adult weevils observed by late May in intensive insect counts (1997-2000) varied among preserves and years. To examine the differences in weevil numbers between preserves within each year, we used $2 \times$ 2 contingency table analyses, using the Bonferroni correction to adjust significant thresholds for multiple comparisons. To evaluate the relative effect of weevil and of wavyleaf thistle on their phenological synchrony, we examined Pearson product-moment correlations of the degree $R$. conicus preceded wavyleaf with weevil phenology and with plant phenology.

\section{Influence of climatic variables}

We used multiple regression to evaluate effects of climatic variables on variation in $R$. conicus abundance, $R$. conicus egg cases per head, $R$. conicus phenology, wavyleaf thistle flower heads, wavyleaf thistle phenology, and weevil-plant phenological synchrony. Sample sizes of the preserve-year combinations for these tests were 23 for thistle flowering effort and phenology (Arapaho: 19922001; Niobrara: 1991-2001), 12 for R. conicus egg cases per wavyleaf flower head (both preserves: 1996-2001); and 8 for weevil abundance, phenology, and phenological synchrony (both preserves: 1997-2000). We used regression (PROC REG: SAS 1999) to identify the model with the lowest mean square error and fewest nonsignificant variables. We included as explanatory variables only those climate variables that our literature review indicated were likely to affect thistle development, or weevil activity, survival, or development (Rathcke and Lacey 1985; Tauber et al. 1986; Tauber et al. 1998; Gassmann and Louda 2001). For R. conicus egg cases per wavyleaf flower head, weevil abundance, and weevil-plant phenological synchrony, we examined both precipitation and GDD in the previous summer, previous autumn, preceding winter and spring; winter and spring relative humidity; and days until both last hard freeze and last freeze in spring. For R. conicus phenology we examined winter and spring GDD, precipitation, and relative humidity as well as days until last hard freeze and last spring freeze. Previous summer and autumn relative humidities were eliminated because they showed diffuse colinearity with the other climate variables (VIF $=8.33,11.28$, respectively). For wavyleaf thistle flowering phenology, wavyleaf flower head availability, and total thistle flower head availability, we examined previous summer, autumn, winter and spring, GDD and precipitation, days until last hard freeze, and days until last freeze in spring.

Influence of biotic variables: direct interaction of R. conicus with C. undulatum

We used multiple regression to evaluate relationships of both $R$. conicus occurrence and oviposition on wavyleaf thistle with variation in three hypothesized biological variables: (1) R. conicus abundance, (2) phenological synchrony of $R$. conicus and wavyleaf thistle; and (3) availability of wavyleaf flower head resources $(N=16$ site-year combinations, 1997-2000). Methods for quantifying site-specific $R$. conicus abundance, $R$. conicus egg cases per head, flower head production, and phenological synchrony paralleled those for preserve-specific estimates described above. We defined "relative occurrence" as the proportion of $R$. conicus adults observed that occurred on wavyleaf thistle out of the total counted on both thistle species at a site. Similarly, we defined "relative oviposition" as the proportion of $R$. conicus egg cases observed that were found on wavyleaf thistle out of the total counted on both thistle species at a site. After analyses of models that included all three biotic variables (weevil abundance, flower head availability, plant-insect synchrony), we used simple regression to test the predictive ability of each variable individually.

Influence of biotic variables: indirect effects among native host plants

To examine $R$. conicus-mediated indirect effects of Platte thistle on wavyleaf thistle, we used multiple regression analyses identical to those used to explore the direct interaction between $R$. conicus and wavyleaf thistle (above), except that the explanatory variables included: (1) total flower heads on both native thistles, and (2) only Platte thistle flower head abundance at a site, instead of wavyleaf flower head abundance. After the multiple regression analysis, we used simple regression to examine the ability of total flower head abundance and abundance of Platte thistle flower heads to explain variation in $R$. conicus egg load on wavyleaf, relative occurrence on wavyleaf, and relative oviposition on wavyleaf. 


\section{Results}

\section{Patterns of variation}

Rhinocyllus conicus abundance, phenology, and oviposition

Adult $R$. conicus abundance varied greatly at both preserves 1997-2000 (Figure 1). There was a preserve $\times$ year interaction ( $G$ test: $\chi_{3}^{2}=223.79, P<0.001$ ), since weevils were more abundant at Arapaho than at Niobrara in 1997 and 1999 (203 and 214\%, respectively), but more abundant at Niobrara than Arapaho in 2000 (345\%). Adult weevil phenology also showed a preserve $\times$ year interaction (Figure 2: $G$ test, $X_{1}^{2}=15.71, P<0.001$ ); weevils were earlier at Niobrara than at Arapaho in 1997 and 2000, but earlier at Arapaho than at Niobrara in 1999. Weevil phenology and weevil abundance were not correlated (Pearson correlation: $r=0.778, P=0.778)$.

Mean $R$. conicus egg load on wavyleaf thistle, as the number of egg cases per flower head per plant (19962001), differed significantly among years at both preserves (Figure 3; Kruskal-Wallis tests: Arapaho, $\chi_{5}^{2}=20.788$, $P \leq 0.001$; Niobrara: $\left.\chi_{5}^{2}=17.722, P=0.003\right)$. At Arapaho, egg load in 1998, the year of highest use, was 201\% higher than in 2001, the year of lowest use (9.4 vs. 3.1 egg cases per head). At Niobrara, egg loads varied from near 0 per head in 2000 to 3.9 in 1997. Mean egg load was 269\% higher at Arapaho than at Niobrara 1996-2001 (Wilcoxon ranked sum test: $\left.\chi_{1}^{2}=31.895, P<0.001\right)$.

Flower head resource availability

The number of wavyleaf thistle flower heads varied moderately from 1992 to 2001 at both preserves (Figure 4). The number of wavyleaf thistle heads varied $2.6 \times$ and $1.8 \times$ among years at Niobrara and at Arapaho, respectively. At both preserves, the most wavyleaf heads occurred in 1993. At Niobrara, the fewest wavyleaf heads occurred in 1996. At Arapaho, the fewest wavyleaf heads occurred in 2000. This variation was not statistically significant, however, likely reflecting small annual sample sizes. The total number of thistle heads available, wavyleaf thistle plus Platte thistle, showed a significant preserve $\times$ year interaction (ANOVA: $F_{9,626}=2.957, P=0.002$ ), reflecting $1.7 \times$ greater flower head production at Niobrara than at Arapaho in 2000. The variation in total number of thistle heads was driven primarily by variation in Platte thistle flowering. Temporal variation in number of heads was similar between preserves.

The phenology of wavyleaf thistle floral development at the two preserves varied significantly (1991-2001). The significant preserve $\times$ year interaction (ANOVA, $F_{1,10}=$ $2.072, P=0.028$ ) reflected generally earlier wavyleaf thistle development at Arapaho than at Niobrara, significantly so in 1998, 1999, and 2000 (Figure 2). At both preserves, temporal variation in thistle flowering phenology was less than temporal variation in weevil phenology. For 1997-2000, coefficients of variation (CV) in the proportion of weevils observed were 1.8 $\times$ larger at Arapaho and $4.2 \times$ larger at Niobrara than were the CVs in the proportion of C. undulatum flower heads initiated by late May, respectively.

Synchrony of $R$. conicus with C. undulatum.

The phenological synchrony between weevils and wavyleaf thistle flower heads varied widely during 19972000 at both preserves, and weevils and flower heads were each ahead half the time (Figure 5). Variation in the degree that $R$. conicus preceded $C$. undulatum correlated strongly with the variation in $R$. conicus phenology (Pearson correlation, $r=0.864, P=0.006$ ), but not with the variation in C. undulatum flowering phenology.

\section{Influence of climatic variables}

Variation in some of the climatic variables contributed significantly to explaining the variation in weevil numbers, weevil phenology, and phenological synchrony of $R$. conicus with wavyleaf thistle, but not the variation in egg load on wavyleaf thistle (Table 1). First, the total number
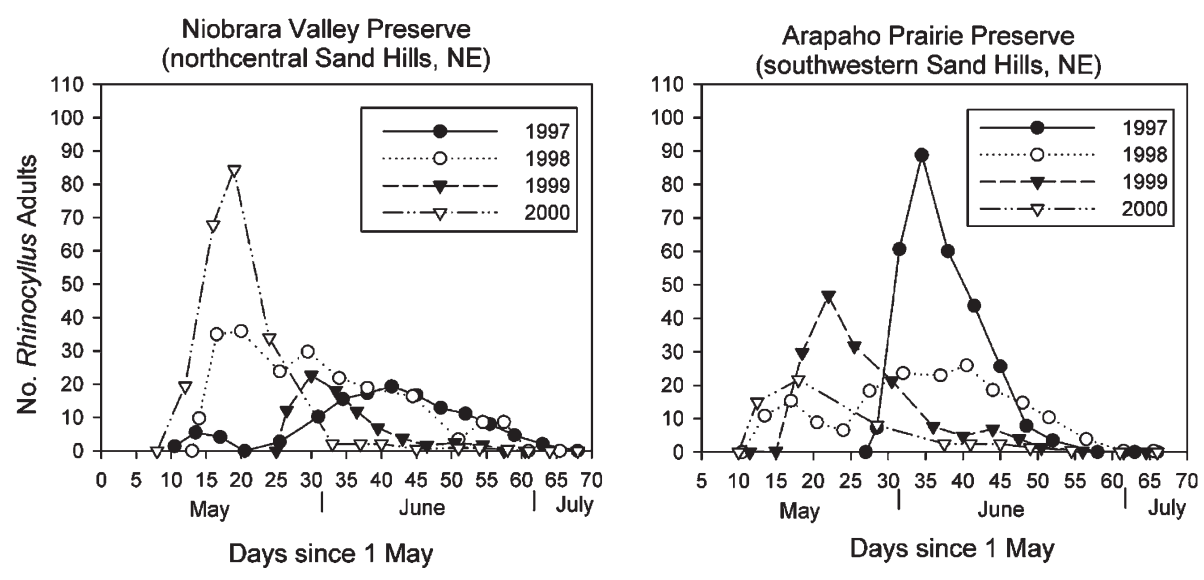

Figure 1. Temporal variation in Rhinocyllus conicus adult abundance within season at preserves, showing running means (counts standardized to $N=10$ thistles for population estimation). 

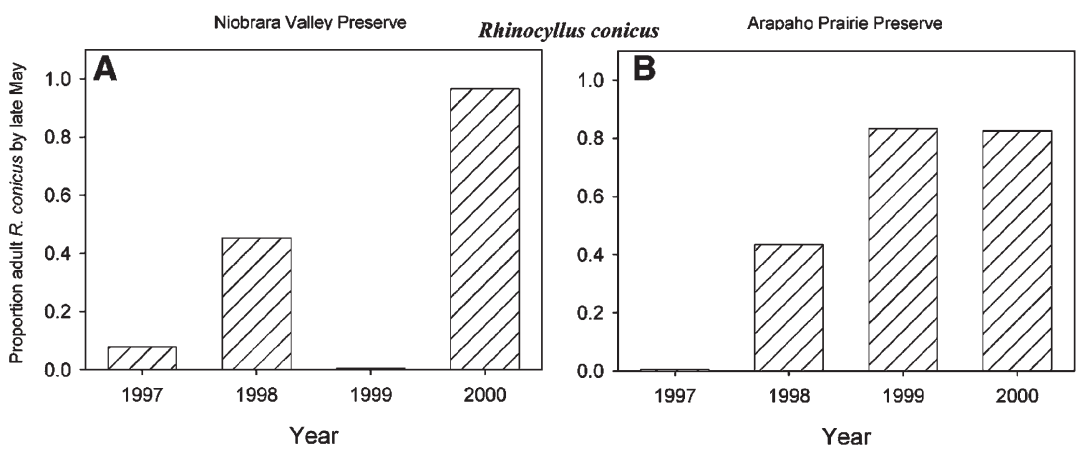

Figure 2. Within season phenology of R. conicus and of wavyleaf thistle (Cirsium undulatum) at preserves: $\mathbf{a}, \mathbf{b}$ proportion of seasonal total of $R$. conicus adults observed by late May; c, d mean (SE) proportion of seasonal total wavyleaf thistle flower heads per plant initiated by late May.
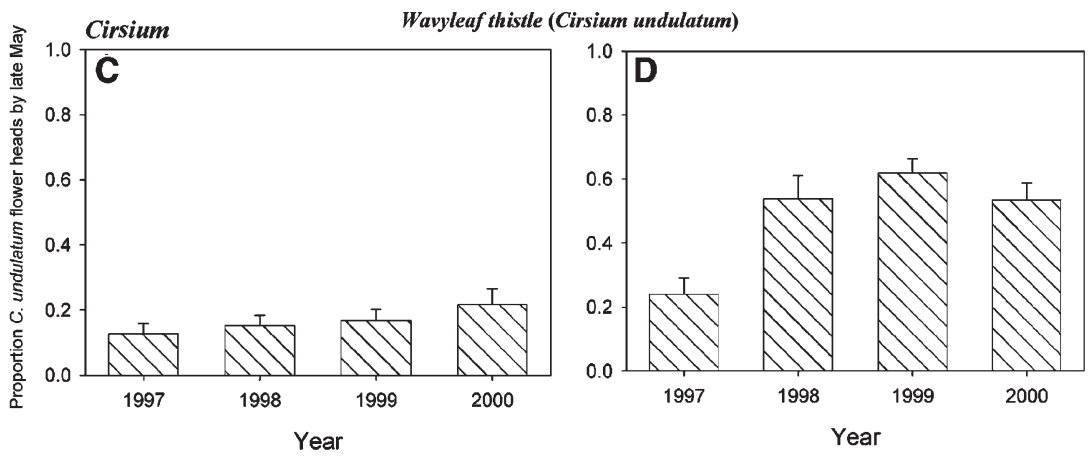

of $R$. conicus adults at a preserve increased with good conditions for plant growth during the preceding 12 months. Weevil abundance increased with increases in previous summer and spring precipitation, and winter and spring GDD (Table 1). Second, the phenology of the $R$. conicus population was accelerated by warm, wet springs. Earlier weevil occurrence was significantly associated with increases in winter GDD, spring GDD, and spring precipitation (Table 1). Spring GDD alone explained 52.6\% of the variation in adult weevil phenology. Spring GDD also contributed significantly to explaining variation in the degree $R$. conicus preceded wavyleaf thistle, explaining $55.4 \%$ of the variation (Table 1 ).

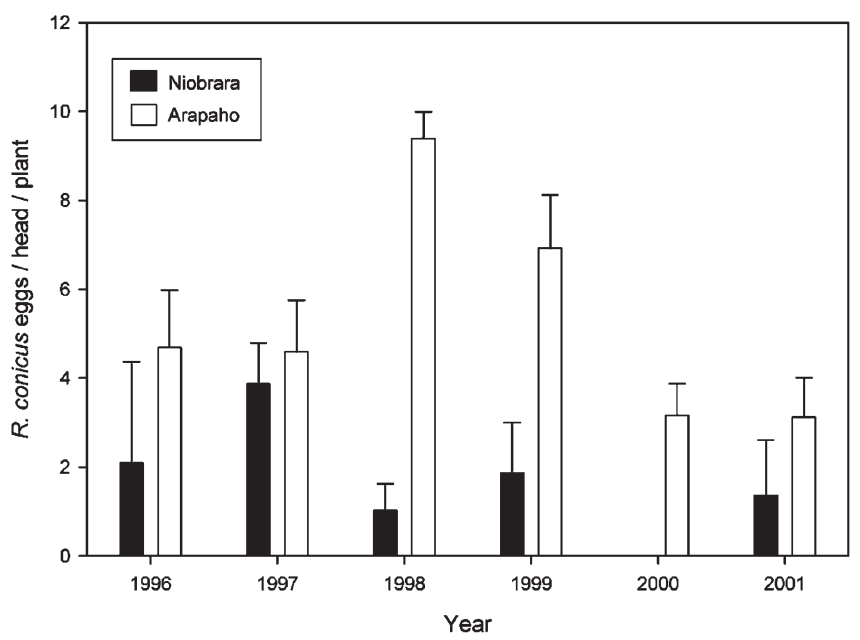

Figure 3. Between-year variation in $R$. conicus egg load on wavyleaf thistle (C. undulatum) at preserves, represented as mean (SE) number of egg cases per flower head per wavyleaf plant at Niobrara Valley (solid bars) and Arapaho Prairie Preserves (open bars).
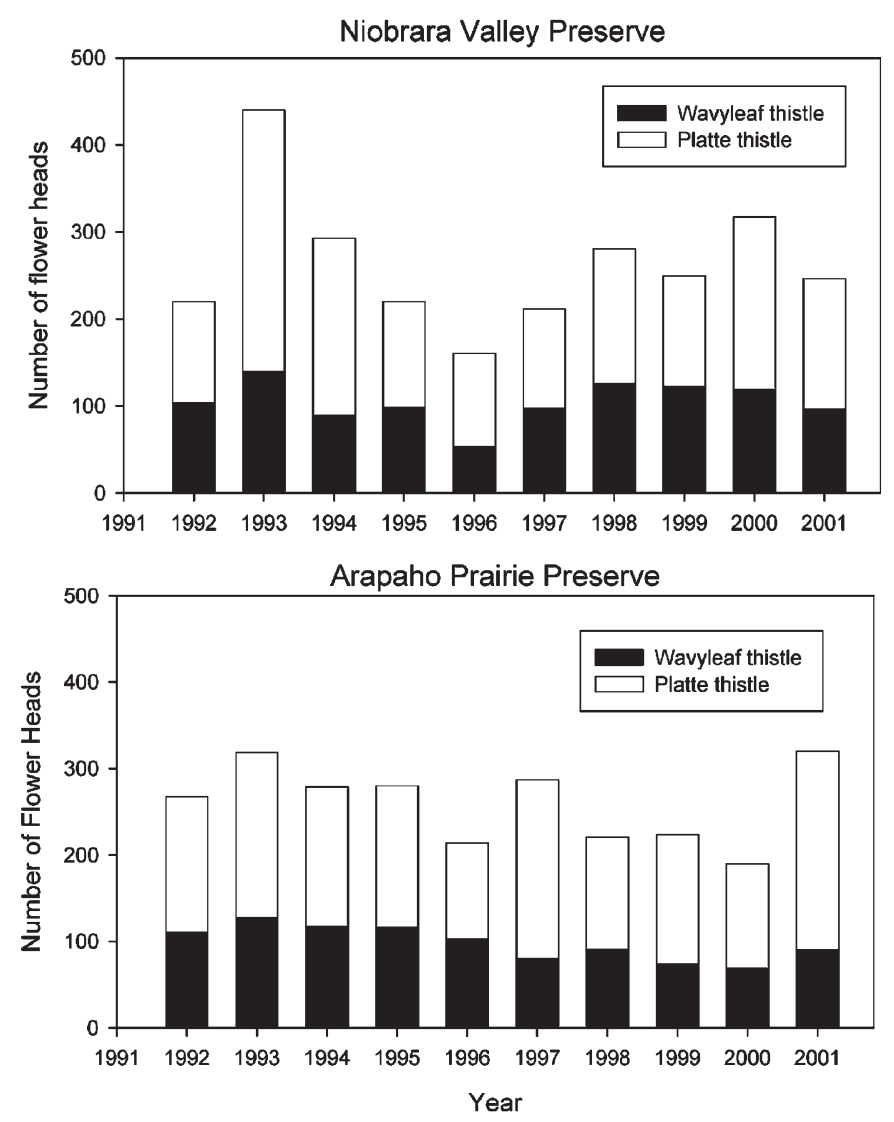

Figure 4. Between-year variation in total number of thistle flower heads produced by both wavyleaf thistle and Platte thistle at Niobrara Valley and Arapaho Prairie Preserves. Numbers of flower heads are standardized to ten plants per species for population level comparisons. Solid portions of bars represent wavyleaf thistle flower heads. Open portions of bars represent Platte thistle flower heads. 
Figure 5. Between-year variation in degree $R$. conicus preceded wavyleaf thistle, C. undulatum (proportion $R$. conicus adults observed-proportion wavyleaf heads initiated, by late May); small absolute values indicate synchrony, while large absolute value indicate asynchrony, at preserve
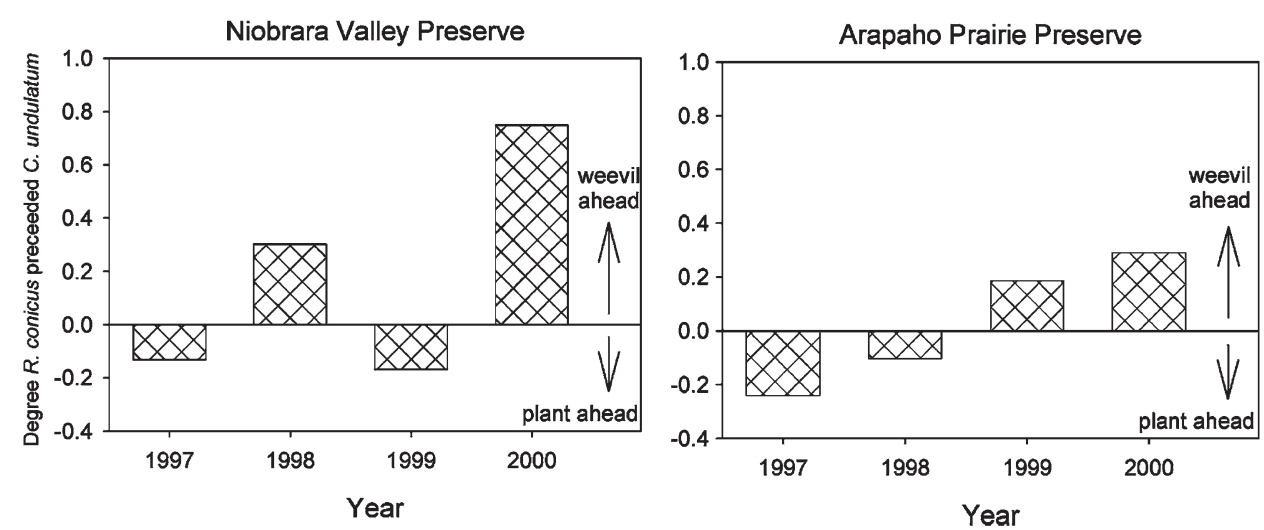

Numbers of wavyleaf flower heads were not related to variation in any of the climatic variables that we expected to influence plant growth and development. Also, wavyleaf thistle phenology was not explained by the climatic parameters. However, the best climate model suggested that days to last spring freeze may have had a marginal influence $\left(F_{1,19}=3.52, P=0.076\right)$ on wavyleaf phenology. Delayed flowering was weakly associated with later spring freezes.

The total number of thistle flower heads, including both wavyleaf and Platte heads at a preserve, however, was related to climatic variation (Table 1). The total number of thistle flower heads at a preserve decreased with increases in previous summer GDD and precipitation (Table 1). Since Platte thistle flowering, but not wavyleaf flowering, decreased significantly with increases in previous summer GDD and precipitation $\left(R^{2}=0.429, F_{2,18}=6.763, P=0.006\right)$, climate influenced the total thistle flower head availability for weevils by influencing Platte thistle flowering effort.
Climate variables did not explain the variation in $R$. conicus egg load on wavyleaf thistle. None of the regressions, using the climatic variables that we hypothesized should influence insect or plant performance, were significant $(P>0.20)$. However, two trends of biological interest appeared. First, $R$. conicus egg load on wavyleaf thistle tended to decrease with increases in spring GDD $\left(F_{1,9}=\right.$ 4.53, $P=0.062)$; and second, egg load on wavyleaf thistle tended to decrease with increases in spring relative humidity $\left(F_{1,9}=3.46, P=0.096\right)$.

Influence of biotic variables: direct interaction of $R$. conicus and C. undulatum

The multiple regression model that included the three biotic variables $-R$. conicus abundance, the phenological synchrony of $R$. conicus and wavyleaf thistle populations, and wavyleaf thistle flower head resource availability - did not explain a significant amount of the variation among sites and years in $R$. conicus egg load on wavyleaf

Table 1. Climate variables that contributed significantly to the explanation of variance in adult Rhinocyllus conicus abundance, $R$. conicus phenology, degree $R$. conicus preceded C. undulatum and total thistle flower head abundance (C. undulatum + C. canescens)

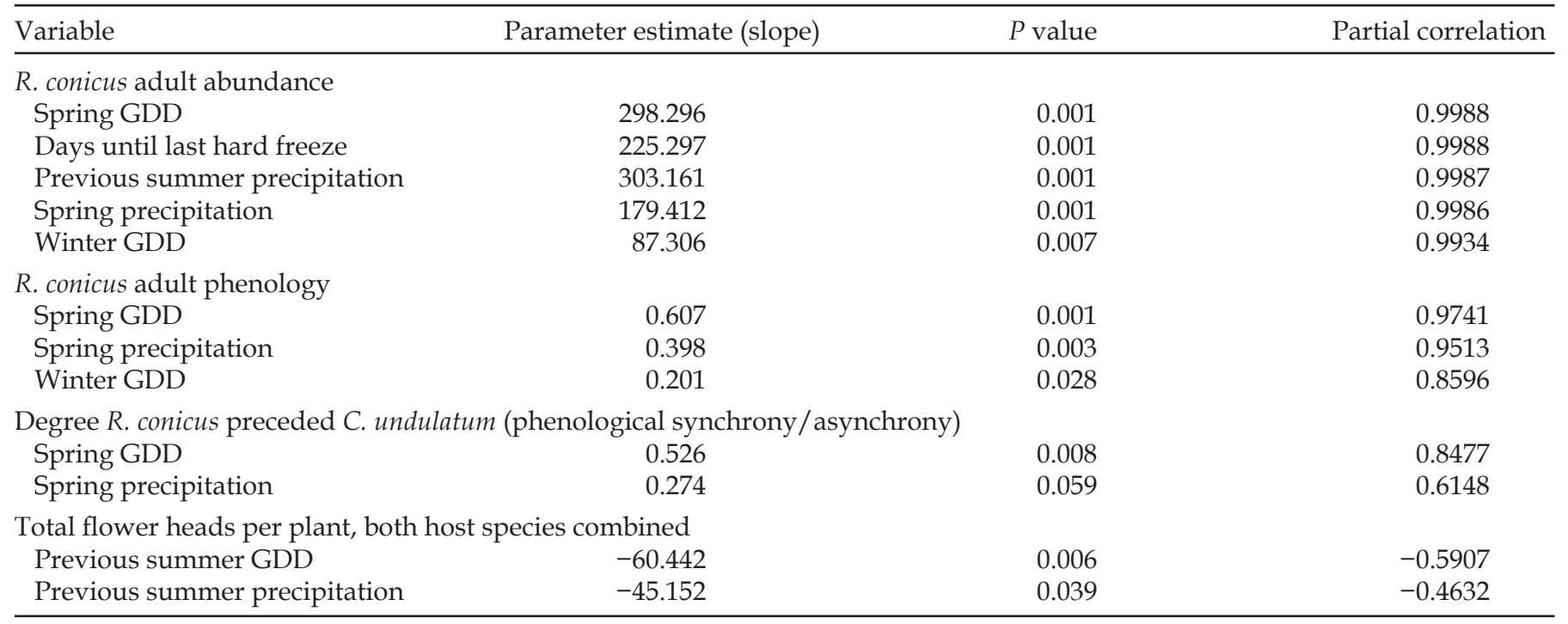

Models for R. conicus phenology, phenological synchrony, and R. conicus abundance are based on 4 years (1997-2000) at both preserves $(N=8)$. Models for total thistle flower head abundance are based on 11 years at Arapaho and 10 years at Niobrara $(N=21)$. “GDD" denotes "growing degree days." Regression statistics. $R$. conicus phenology: $N=8, P<0.003, R{ }^{2}=0.961$, degree $R$. conicus preceded C. undulatum: $N=8, P=0.019, R^{2}=0.795 ; R$. conicus abundance: $N=8, P=0.005, R^{2}=0.998$; Flower head per plant (both spp.): $N=21, P=0.02, R^{2}=0.345$ 
thistles $\left(F_{3,12}=2.165, P=0.145\right)$. Further, none of these three biotic variables were individually significant predictors of variation in $R$. conicus egg load on wavyleaf thistle. Therefore, variables concerning only the pairwise interaction of the herbivore and populations of this host plant in sand prairie were insufficient to explain variation in oviposition level and damage.

\section{Influence of biotic variables: indirect effects among native host plants}

The multiple regression model that included total flower heads resources (produced by both wavyleaf and Platte thistles), weevil abundance, and weevil-wavyleaf thistle phenological synchrony did explain a significant amount of the variation in $R$. conicus egg load on wavyleaf thistles (Table 2). Each of these biotic variables contributed significantly to the multiple regression model that explained the most variation in $R$. conicus egg load on wavyleaf thistle (Table 2). Mean egg load on wavyleaf flower heads increased with the combined effects of increases in weevil abundance as well as decreases in asynchrony (measured as the degree $R$. conicus preceded wavyleaf thistle), and in total thistle heads available at a site (Table 2a). Individually, however, none of the biotic variables by itself explained a significant portion of the variation (linear regressions, $P>0.20$ ).

The proportion of total $R$. conicus adults that were found on wavyleaf thistle ("weevil relative occurrence") increased with decreases in degree $R$. conicus preceded wavyleaf thistle and with decreases in total flower head resources (Table $2 b$ ). The variation in total flower head resources was best explained by variation in Platte thistle flower heads (Figure 6e).

Specifically, spatial and temporal patterns in R. conicus egg loads on wavyleaf thistle flower heads were inversely related to the availability of Platte thistle flower heads (Figure 6). The proportion of total R. conicus egg cases that were found on wavyleaf thistle ("weevil relative oviposition") increased significantly as $R$. conicus abundance increased, and decreased significantly as the degree $R$. conicus preceded wavyleaf thistle and as total flower heads increased (Table 2c). Further, weevil relative oviposition was not affected by the availability of wavyleaf flower heads $(P>0.20)$, but decreased as the total number of heads increased (Figure 6). Since the total number of heads available at a site was the sum of wavyleaf thistle plus Platte thistle heads and wavyleaf thistle flowering varied only moderately, variation in Platte thistle flowering drove the significant variation in total resource availability, and this variation significantly influenced egg load on wavyleaf thistle (Figure 6). Simple linear regression models, with number of Platte thistle heads as the independent variable, explained more variation in both the proportion of $R$. conicus adults (Figure 6e) and the proportion of egg cases (Figure 6f) on wavyleaf thistle than did models with the number of wavyleaf heads alone (Figure $6 \mathrm{a}, \mathrm{b}$ ) or with the total number of flower heads of both species (Figure 6c, d). Thus, the strongest individual predictor for both relative occurrence and relative oviposition of $R$. conicus on wavyleaf thistle was the number of Platte thistle flower heads available.

\section{Discussion}

Three important points emerged from this study. First, our results show that the native wavyleaf thistle (C. undulatum) experienced associational defense from oviposition and larval feeding damage by the exotic R. conicus where the other native thistle in sand prairie, Platte thistle (C. canescens), was doing well; R. conicus oviposition on wavyleaf flower heads decreased as the availability of Platte thistle flower heads increased. This finding

Table 2. Effect of biotic variables on $R$. conicus oviposition (mean egg cases per wavyleaf, Cirsium undulatum, flower head), relative occurrence of $R$. conicus adults on $C$. undulatum and relative use of wavyleaf thistle by $R$. conicus

\begin{tabular}{|c|c|c|c|}
\hline Variable & Parameter estimate (slope) & $P \leq$ & Partial correlation \\
\hline \multicolumn{4}{|l|}{ R. conicus egg cases/wavyleaf thistle head ${ }^{a}$} \\
\hline R. conicus adult abundance & 0.023 & 0.022 & 0.6056 \\
\hline Degree $R$. conicus preceded C. undulatum & -6.354 & 0.044 & -0.5443 \\
\hline Total flower heads/plant for both native thistles & -0.036 & 0.034 & -0.5682 \\
\hline \multicolumn{4}{|l|}{ Relative occurrence of $R$. conicus on wavyleaf thistle ${ }^{\mathrm{b}}$} \\
\hline Adult abundance of $R$. conicus & -0.001 & 0.266 & -0.3194 \\
\hline Degree $R$. conicus preceded wavyleaf thistle & -0.629 & 0.003 & -0.7375 \\
\hline Total flower heads/plant for both native thistles & -0.003 & 0.008 & -0.6787 \\
\hline \multicolumn{4}{|c|}{ Relative oviposition use of wavyleaf thistle by $R \cdot$ conicus $^{c}$} \\
\hline Adult abundance of $R$. conicus & 0.002 & 0.046 & 0.5396 \\
\hline Degree $R$. conicus preceded wavyleaf thistle & -0.556 & 0.001 & -0.8493 \\
\hline Total flower heads/plant for both native thistles & -0.004 & 0.001 & -0.7666 \\
\hline
\end{tabular}

Relative occurrence is defined as the proportion of R. conicus adults observed on wavyleaf compared to Platte thistle. Relative use is defined as the proportion of $R$. conicus egg cases on wavyleaf compared to Platte thistle

${ }^{a}$ Regression of $R$. conicus eggs per wavyleaf head: $N=16, P=0.039, R^{2}=0.489$, Intercept $=8.95$

${ }^{\mathrm{b}}$ Regression of $R$. conicus relative occurrence on wavyleaf: $N=16, P=0.001, R^{2}=0.716$, Intercept $=1.27$

${ }^{\mathrm{c}}$ Regression of $R$. conicus relative use of wavyleaf thistle: $N=16, P<0.001, R^{2}=0.771$, Intercept $=1.259$ 
is among the first evidence that an exotic herbivore can mediate an indirect interaction between two native plants (see also Hails and Crawley 1991). Second, both absolute abundance of $R$. conicus and phenological synchrony of its activity with wavyleaf thistle flower head production also contributed to the variation in $R$. conicus damage to wavyleaf thistle populations. Third, the results argue that accurate prediction of ecological risk to a native host plant population from an exotic insect species requires information on both occurrence and phenology of other potential host plants within the recipient communities. In the following, we discuss each of these findings and its implications.

\section{Associational defense provided by another native plant}

We found strong evidence of associational defense for wavyleaf thistle against $R$. conicus damage in the pres- ence of successful flowering by an alternate, newly adopted native host plant, Platte thistle. Greater availability of Platte thistle flower heads decreased R. conicus use of wavyleaf thistle flower heads. Both relative occurrence and relative oviposition of $R$. conicus on wavyleaf thistle, compared to occurrence and oviposition on Platte thistle, were inversely related to the number of Platte thistle heads (Figure 6e, f). This result was unexpected, given that the dynamics of Platte thistle flower head production alone significantly explained the variation in $R$. conicus egg load on Platte thistle (Russell and Louda 2004). The strength of associational defense that wavyleaf thistle experienced with Platte thistle was influenced partly by climatic variation and its effect on Platte thistle flowering effort. More total thistle flower heads were produced in our sand prairie sites in years following cool, dry summers; this reflected the negative flowering response of Platte thistle to higher GDD and precipitation in the previous
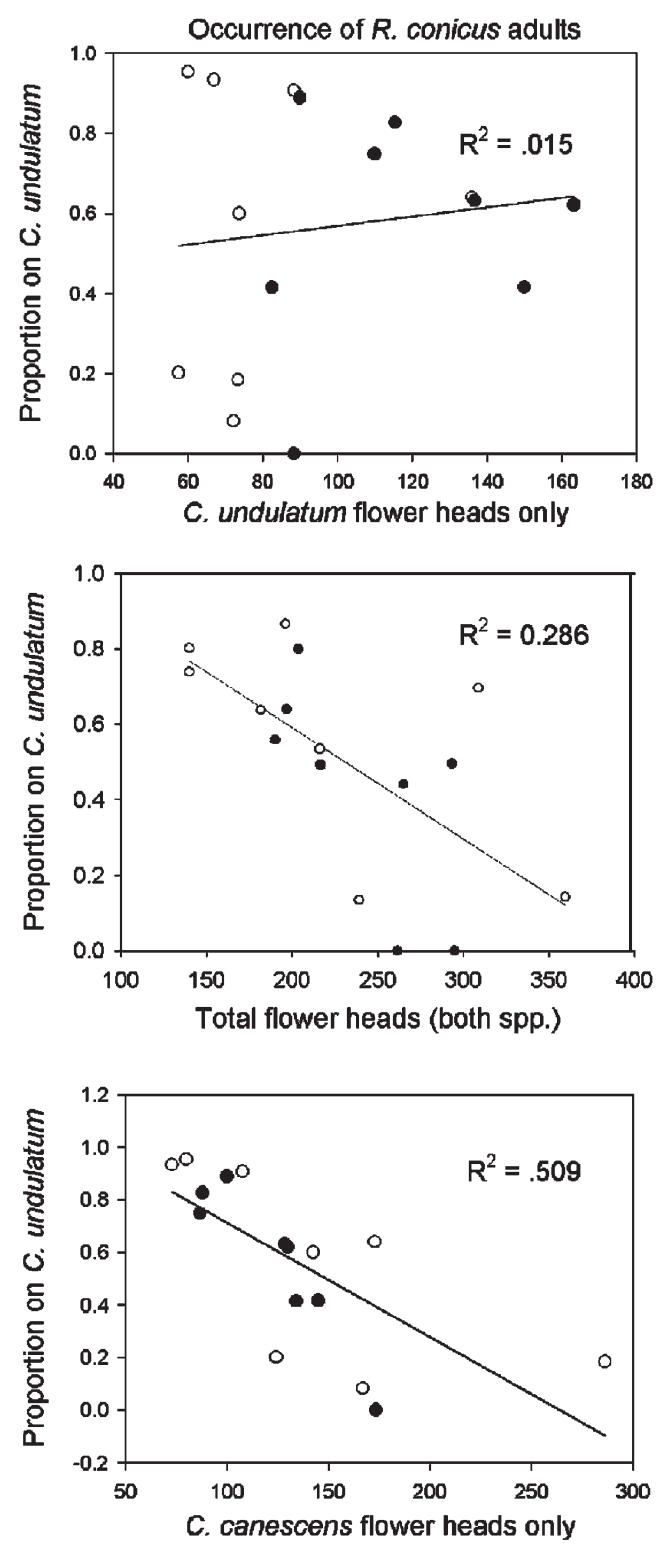
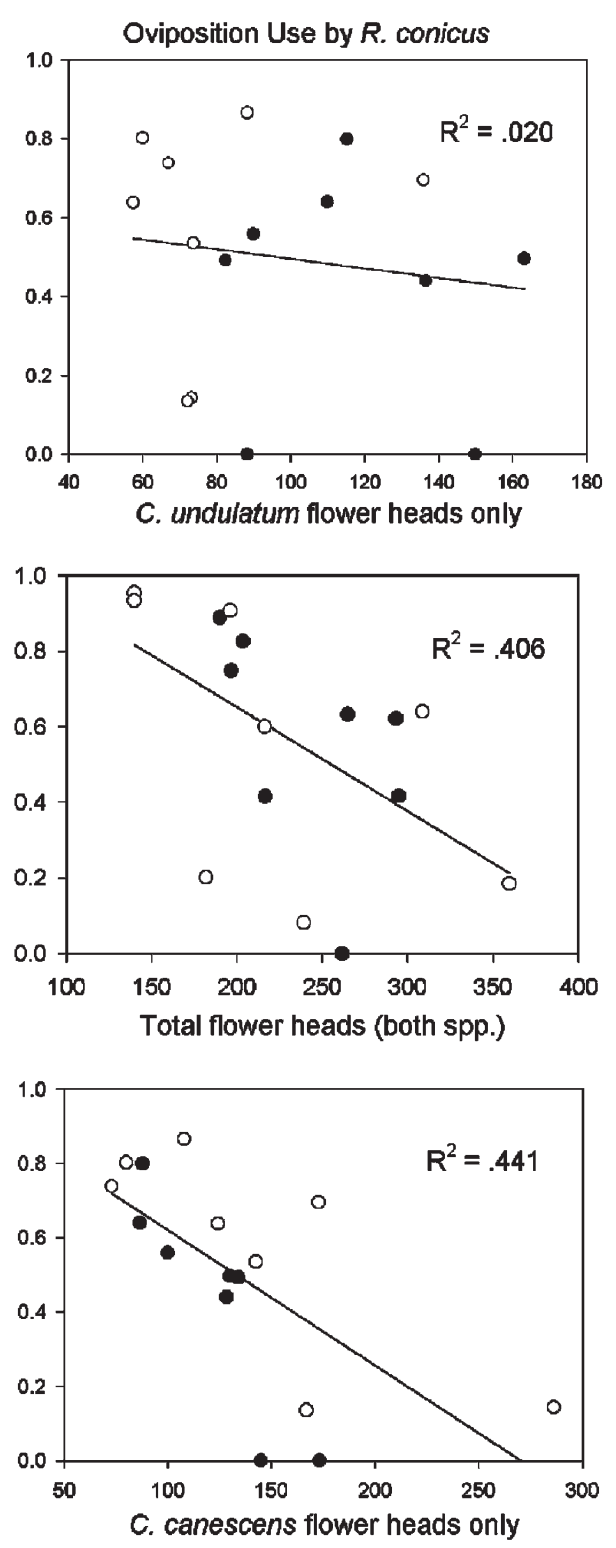

Figure 6. Occurrence of $R$. conicus (a, c, e) and its oviposition use (b, d, f) of wavyleaf thistle (C. undulatum), relative to occurrence and use of the other host plant available, Platte thistle (C. canescens), at Niobrara Valley (solid circles) and Arapaho Prairie Preserves (open circles), as a function of the number of flower heads standardized to ten plants per population: $(\mathbf{a}, \mathbf{b})$ for wavyleaf thistle plants only; (c, d) for both native thistle species within a site; and (e, f) for Platte thistle plants only. Least squares regressions: (a) proportion of $R$. conicus adults on wavyleaf thistle $=0.452$ +0.001 (wavyleaf thistle flower heads), $P=0.651$, (b) proportion of $R$. conicus eggs on wavyleaf thistle $=0.617+0.001$ (wavyleaf thistle flower heads), $P=0.599$, (c) proportion of $R$. conicus adults on wavyleaf thistle $=1.2-0.003$ (total thistle flower heads), $P=$ 0.033 , (d) proportion of $R$. conicus eggs on wavyleaf thistle $=1.181-$ 0.003 (total thistle flower heads), $P=0.008$, (e) proportion of R. conicus adults on wavyleaf thistle = 1.146-0.004 (Platte thistle flower heads), $P=0.002$; (f) proportion of $R$. conicus eggs on wavyleaf thistle $=0.986-0.004$ (Platte thistle flower heads), $P=0.005$ 
summer. We know no other studies that have shown that a native plant suffered less damage by an exotic insect herbivore when it was associated with an alternative native host plant species.

Atsatt and O'Dowd (1976) proposed that a plant would experience associational defense when it occurs with an alternate host species, if the alternate host drew the herbivores away. However, the theory developed subsequently predicts that such associational defense will only occur if the alternate host does not induce herbivore immigration into the shared patch (Holt 1977, Vandermeer 1989). In most cases, the mechanism underlying associational defense is not herbivore attraction by the alternate host; instead, neighboring plants either interfere with herbivore detection of hosts or augment predators of the herbivore (Hamback and Beckerman 2003). In Sand Hills prairie, which lacks $R$. conicus' target weed musk thistle (C. nutans), associational defense of wavyleaf thistle may occur because $R$. conicus dispersal from native thistle patches may be relatively limited. A recent study showed that isolated wavyleaf plants, those more than $20 \mathrm{~m}$ from other thistles, receive significantly fewer $R$. conicus eggs than do those in a patch of thistles (M. Manning and S. M. Louda, unpublished data).

The asymmetry of the indirect effects between wavyleaf thistle and Platte thistle likely reflects relative flowering phenology. Platte thistle flowers before wavyleaf thistle (Louda 1998), so Platte thistle flower heads generally are more available than wavyleaf flower heads during $R$. conicus' oviposition period, especially when the weevil's phenology is early. Associational defense of wavyleaf thistle could arise if weevils ovipositing first on Platte thistle are unlikely to move to wavyleaf thistle, or if adult females produce a limited number of eggs. Accumulating evidence suggests that the relative phenologies of prey often may determine the direction of asymmetry of predator-mediated indirect effects (Chaneton and Bonsall 2000). Alternatively, the asymmetry in this case may reflect an innate preference of $R$. conicus for Platte thistle over wavyleaf thistle; this hypothesis is currently being evaluated (M. Manning and S. M. Louda, unpublished data).

One prediction emerging from current theory is that if $R$. conicus populations increase numerically where Platte thistle flower heads are abundant, then wavyleaf thistle eventually could suffer greater damage, rather than less damage, near Platte thistle than when it occurs alone ("associational susceptibility") (Holt 1977). We predict that $R$. conicus damage to wavyleaf thistle in sand prairie is likely to increase in the future, but we suggest a different mechanism. The data show that Platte thistle populations have declined dramatically since $R$. conicus first invaded our study sites (Louda and Arnett 2000, Louda et al. 2003). Therefore, as Platte thistle density declines, we expect that $R$. conicus will be forced to delay oviposition and will more heavily utilize and damage the available wavyleaf thistles.
Phenological synchrony-modified effects of herbivore abundance

In some years and sites, phenological synchrony between $R$. conicus and wavyleaf thistle populations, specifically the degree to which adult weevil activity preceded wavyleaf flower head development superceded the effect of $R$. conicus density per se in predicting egg load on wavyleaf thistle. For example, at the "Gate" site at Arapaho, when $88 \%$ of all $R$. conicus but only $40 \%$ of wavyleaf heads occurred by late May, $R$. conicus egg loads on wavyleaf thistle were the lowest we ever observed at this preserve. Similarly, at the "Inner Salzman" site at Niobrara, when $95 \%$ of all $R$. conicus adults but only $21 \%$ of wavyleaf flower heads occurred by late May, we found no egg cases on wavyleaf thistles. These low egg loads occurred despite high numbers of adult weevils. Consistent with the indirect effect hypothesis of associational defense, when $R$. conicus emerged early, then the low egg loads on wavyleaf thistle were matched by heavy use of Platte thistle (.$\underline{6}$, Russell and Louda 2004).

Such phenological synchrony of herbivores and host plant individuals is recognized as affecting variation in damage among plants within a population (Mopper and Simberloff 1995; Angulo-Sandoval and Aide 2000). Further, variation in phenological synchrony of insects and host plant populations has been shown to affect spatial structure (Rodriguez et al. 1994) and size of insect populations (Kerslake and Hartley 1997; Hunter and Elkington 2000). By contrast, the effects of variation in phenological synchrony on plant populations have rarely been examined (Russell and Louda 2004). Thus this study, along with our previous study of Platte thistle (Russell and Louda 2004) provides quantitative evidence that variation in phenological synchrony, of an exotic floral and seed-feeding insect herbivore population with its adopted native host plant populations, affects levels of use and damage.

Weevil phenology and total abundance both were strongly affected by climate (Table 1). Weevil phenology was accelerated by a warm winter-spring periods and by spring precipitation. Temperature has been reported to affect R. conicus phenology (Smith and Kok 1985, 1987), but our results also suggest the importance of spring moisture, independent of temperature variation in winter or spring, possibly through an effect on overwintering success. The important result, though, was the influence of climatic parameters on the synchrony of the insect population and each of the two host plant populations through its effect on weevil phenology. Thus, climate apparently exerted an indirect influence on $R$. conicus damage to wavyleaf thistle, not only by affecting total flower heads and Platte thistle flower head availability but also by affecting weevil phenology and population density. 


\section{Prediction of exotic insect impact on native host plants}

Understanding the causes of large temporal and spatial variation in damage by floral and predispersal seedfeeding insects will enhance our ability to predict damage to native plants by exotic insect herbivores. Accurate prediction of damage would be valuable both when exotic insects are considered for release as weed biological control agents or when invasive insects expand their ranges into new regions. However, few studies have simultaneously considered multiple, possibly interacting mechanisms driving variation in damage, both for native assemblages and for prerelease evaluations of insect biocontrol agents. Our results strongly suggest that prediction of nontarget damage on potential native host plants by exotic insects, like $R$. conicus, is not possible if only the pairwise interaction between herbivore and a particular host plant is considered. Instead, accurate prediction of ecological risk to less preferred native host plants will require consideration of the abundance and phenology of resource availability on all potential host plant species within potential recipient communities.

\section{Acknowledgments}

We thank A. E. Arnett, R. W. Otley, T. A. Rand, J. Randall, and K. Shea for constructive discussions, and all our dedicated student field assistants since 1990, especially K. Christiansen Engel, A. Rogers Kula, J. Zimmer, and TNC biotechnicians at the Niobrara Preserve who did the intensive insect counts (19972001); C. W. O'Brien for weevil identifications; S. Kachman and A. M. Parkhurst for statistical advice; A. A. Steuter, M. Behrens, and J. Lucksinger of the Nature Conservancy for discussions and encouragement; and the staffs of both the Niobrara Valley Preserve and Cedar Point Biological Station who, each in their own way, greatly facilitated our work. We appreciate the financial support provided by the Katherine Ordway and Rodney Johnson Stewardship Endowments of the Nature Conservancy, the University of Nebraska Research Council, The National Science Foundation (DEB9221065, DEB9616210) and the USDA-NRI (\#2001-35320-09882).

\section{References}

Aizen MA, Patterson WA (1995) Leaf phenology and herbivory along a temperature gradient: a spatial test of the phenological window hypothesis. J Veg Sci 6:543-550

Angulo-Sandoval P, Aide TM (2000) Seasonal variation in leaf characteristics and food selection by larval noctuids on an evergreen Mediterranean shrub. Acta Oecol 21:257-265

Atsatt PR, O'Dowd DJ (1976) Plant defense guilds. Science 193:24-29

Bevill RL, Louda SM, Stanforth LM. (1999) Protection from natural enemies in managing rare plant species. Cons Biol 13:1323-1331

Bleed A, Flowerday C (1989) An Atlas of the Sand Hills. Resource Atlas no. 5. University of Nebraska, Institute of Agriculture and Natural Resources, Lincoln, NE
Chaneton EJ, Bonsall MB (2000) Enemy-mediated apparent competition: empirical patterns and the evidence. Oikos 88:380-394

Crawley MJ (1983) Herbivory: the dynamics of animal-plant interactions. University of California Press, Berkeley

Crawley MJ (1992) Seed predators and plant population dynamics. In: Fenner M, (ed) Seeds: the ecology of regeneration in plant communities. CAB International, Wallingford, UK, pp 157-192

Gassmann A, Louda SM (2001) Rhinocyllus conicus: initial evaluation and subsequent ecological impacts in North America. In Wajnberg E, Scott JK, Quimby PC, (eds) Evaluating indirect ecological effects of biological control. CABI Publishing, CABI International, Wallingford, Oxon, UK, pp 147-183

Great Plains Flora Association (1986) Flora of the Great Plains. University Press of Kansas, Lawrence, KS

Hails RS, Crawley MJ (1991) The population dynamics of an alien insect: Andricus quercuscalicis (Hymenoptera: Cynipidae). J Anim Ecol 60:545-562

Hamback PA, Beckerman AP (2003) Herbivory and plant resource competition: a review of two interacting interactions. Oikos 101:26-37

Holt RD (1977) Predation, apparent competition and the structure of prey communities. Theor Popul Biol 12:197-229

Holt RD, Hochberg ME (2001) Indirect interactions, community modules and biological control: a theoretical perspective. In: Wajnberg E, Scott JK, Quimby PC, (eds) Evaluating indirect ecological effects of biological control. CABI Publishing, Wallingford, pp 13-37

Hunter AF, Elkinton J (2000) Effects of synchrony with host plant on populations of spring-feeding Lepidopteran. Ecology 81:1248-1261

Janzen DH (1971) Seed predation by animals. Annu Rev Ecol Syst 2:465-492

Kelly CA, Dyer RJ (2002) Demographic consequences of inflorescence-feeding insects for Liatris cylindracea, an iteroparous perennial. Oecologia 132:350-360

Kerslake JE, Hartley SE (1997) Phenology of winter moth feeding on common heather: effects of source population and experimental manipulation of hatch dates. J Anim Ecol 66:375-385

Koenig WD, Knops JMH (2000) Patterns of annual seed production by northern hemisphere trees: a global perspective. Am Nat 155:59-69

Lamp WO, McCarty MK (1981) Biology and ecology of Platte thistle (Cirsium canescens). Weed Sci 29:686-692

Leimu R, Syrjanen K, Ehrlen J, Lehtila KP (2002) Pre-dispersal seed predation in Primula veris: among-population variation in damage intensity and selection on flower number. Oecologia 133:510-516

Louda SM (1982a). Distribution ecology: Variation in plant recruitment in relation to insect seed predation. Ecol Monogr 52:25-41

Louda SM (1982b). Limitation of the recruitment of the shrub Haplopappus squarrosus (Asteraceae) by flower- and seedfeeding insects. J Ecol 70:43-53 
Louda SM (1983) Seed predation and seedling mortality in the recruitment of a shrub, Haplopappus venetus (Asteraceae), along a climatic gradient. Ecology 64:511-521

Louda SM (1989) Differential predation pressure: a general mechanism for structuring plant communities along complex environmental gradients? Trends Ecol Evol 4:158-159

Louda SM (1998) Population growth of Rhinocyllus conicus (Coleoptera: Curculionidae) on two species of native thistles in prairie. Environ Entomol 27:834-841

Louda SM (2000) Negative ecological effects of the musk thistle biocontrol agent, Rhinocyllus conicus Fröl. In: Follet PA, Duan JJ (eds) Nontarget effects of biological control. Kluwer, Boston, pp 215-243

Louda SM, Arnett AE (2000) Predicting non-target ecological effects of biological control agents: evidence from Rhinocyllus conicus. In: Spencer NR (ed) Proceedings of the 10th international symposium on the biological control of weeds. Montana State University, Bozeman, pp 551-567

Louda SM, Potvin MA (1995) Effect of inflorescence-feeding insects in the demography and lifetime fitness of a native plant. Ecology 76:229-245

Louda SM, Rodman JE (1996) Insect herbivory as a major factor in the shade distribution of a native crucifer (Cardamine cordifolia A. Gray, bittercress). J Ecol 84:229-238

Louda SM, Dixon PM, Huntly NJ (1987) Herbivory in sun and shade at a natural meadow-woodland ecotone in the Rocky Mountains. Vegetation 72:141-149

Louda, SM, Kendall D, Connor J, Simberloff D (1997) Ecological effects of an insect introduced for the biological control of weeds. Science (USA) 277: 1088-1090

Louda SM, Kendall D, Connor J, Simberloff D (1997) Ecological effects of an insect introduced for the biological control of weeds. Science 277:1088-1090

Louda SM, Arnett AE, Rand TA, Russell FL (2003) Invasiveness of some biological control insects challenges adequacy of ecological risk assessment and regulation. Cons Biol 17:1-11

Maron JL, Combs JK, Louda SM (2002) Insect herbivory on thistles: congruent interaction strengths in coastal vs. continental dunes. Ecology 83:3382-3392

Mopper S, Simberloff D (1995) Differential herbivory in an oak population: the role of plant phenology and insect performance. Ecology 76:1233-1241
Rathcke B, Lacey EP (1985) Phenological patterns of terrestrial plants. Ann Rev Ecol Syst 16:264-271

Rodriguez J, Jordano D, Fernandez Haeger J (1994) Spatial heterogeneity in a butterfly-host plant interaction. J Anim Ecol 63:31-38

Rose KA, Louda SM, Rees M (2005) Demographic and evolutionary impacts of native and invasive insect herbivores on Cirsium canescens. Ecology 86:453-465

Russell FL, Louda SM (2004) Phenological synchrony affects interaction strength of an exotic weevil with Platte Thistle, a native hostplant. Oecologia 139:525-534

Smith TJ III (1987) Seed predation in relation to tree dominance and distribution in mangrove forests. Ecology 68:266-273

Smith LM, Kok LT (1985) Influence of temperature on the development and mortality of immature Rhinocyllus conicus (Coleoptera: Curculionidae). Environ Entomol 14:629-633

Smith LM, Kok LT (1987) Influence of temperature on oviposition, quiescence, and mortality of Rhinocyllus conicus (Coleoptera: Curculionidae). Environ Entomol 16:971-974

Solbreck C, Sillen-Tullberg B (1986) Seed production and seed predation in a patchy and time-varying environment. Dynamics of a milkweed-tephritid fly system. Oecologia 71:51-58

Tahvanainen JO, Root RB (1972) The influence of vegetational diversity on the population ecology of a specialized herbivore, Phyllotreta cruciferae (Coleoptera: Chrysomelidae). Oecologia 10:321-346

Tauber MJ, Tauber CA, Masaki S (1986) Seasonal adaptations of insects. Oxford University Press, New York

Tauber MJ, Tauber CA, Nyrop JP, Villani MG (1998) Moisture, a vital but neglected factor in the seasonal ecology of insects: hypotheses and tests of mechanisms. Environ Entomol 27:523-530

Vandermeer J (1989) The ecology of intercropping. Cambridge University Press, Cambridge

Zwölfer H, Harris P (1984) Biology and host specificity of Rhinocyllus conicus (Froel.) (Col., Curculionidae), a successful agent for biocontrol of the thistle, Carduus nutans L. Z Angew Entomol 97:36-62 